\title{
Nutritional Analysis of School Meals at Ruhanga Development School in Uganda
}

\author{
L. Pearson and L. Santos-Merx \\ Leeds Trinity University College, Leeds LS18 5HD, UK
}

Within a 4 week undergraduate placement at the Ruhanga Development School in Uganda a project was carried out with the aim of analysing the meals offered to the pupils against the daily nutrient requirement values for school children ${ }^{(1)}$. An additional aim was to obtain the weight and height of a sample of pupils. The school opened in 2008 with 30 children and has been grown and currently accommodates approximately 450 pupils.

The meals analysed were a porridge drink served in each morning break and 4 lunches ( 2 within each week). An average sample of $219 \mathrm{~g}$ of the porridge drink (out of 80) consisted of maize flour and water. The 4 lunches did not vary much in terms of ingredients, and consisted of maize flour and kidney beans sauce with cabbage and/or onions and also salt. Samples taken for measurement varied between 10 and 20 for each meal giving average portions between 381 and $392 \mathrm{~g}$. The nutrient values of the weighed food were obtained from a food composition table ${ }^{(2)}$.

Both the porridge drink and lunch together accounted in average for $23 \%$ and $19 \%$ of the daily energy requirement for a $3-5$ and a 7-10 year old child, respectively. This low intake was mainly due to low amounts of fat. Low intakes were also found for some other nutrients however, protein, iron and sodium were not as low, especially for the younger children (see Table). Despite not knowing the exact food intake outside school hours it is unlikely that the children will receive the remaing $77-81 \%$ of their energy and nutrients daily requirements at home.

\begin{tabular}{lccccccc}
\hline & Energy & Protein & Fat & Iron & Vit C & Sodium* & Calcium* \\
\hline \% Daily requirements 3-5 y & 23.5 & 40.9 & 2.7 & 37.5 & 6.9 & 37.3 & 12.3 \\
\% Daily requirements 7-10y & 18.9 & 28.0 & 2.2 & 23.5 & 6.9 & 21.8 & 12.3 \\
\hline Values are averages for four lunches and and morning breaks against percentage of daily requirements;
\end{tabular}

Values are averages for four lunches and and morning breaks against percentage of daily requirements

* values for 4-6 years old

Anthropometric data (height and weight) were taken from 51 pupils by using local methods. Data from 11 children were not considered due to not knowing their birthday date (orphans) leaving a sample of 20 boys (aged between 4 and 9.5 years) and 20 girls (aged between 2 and 10 years). The majority of children had normal BMI and 3 boys and 4 girls had their BMI within the overweight/obese categories. No BMI under the thinness category was found. The latter could be possibly due to not being a representative sample or measurement errors.

Knowing the school is located within an undeveloped area, the food supplied within school time should be the major contributor for a child́s daily nutritional needs to prevent negative effects on growth and learning among other nutritional deficiences. As a result from this study it has been recommended that the children should consume particularly more energy (fat) and calcium whilst at school by adding milk to porridge and cooking oils to lunch. A further recommendation was to develop a fruit and vegetable garden within the school area growing plants rich in fat, such as groundnuts and avocado, and fruits rich in vitamin $\mathrm{C}$ to increase the bioavailabiltity of iron plant sources.

Ruhanga School is the only school in the area that feeds the children at break time. Despite not being a nutritionally strong snack it contributes invaluably to the children's development. Currently, money is the main limitation for the improvement of the quality of schools meals. However, the school is looking at ways of getting the extra funding.

1. Savage-King F \& Burgess A (1993) Nutrition for Developing Countries. $2^{\text {nd }}$ ed. Oxford: Oxford University Press.

2. McCance RA et al. (2002) McCance and Widdowson's The Composition of Foods. $6^{\text {th }}$ ed. London: Royal Society of Chemistry. 